\title{
Does Etomidate Increase Vasopressor Requirements in Patients Needing Mechanical Ventilation?
}

\author{
Mary Elliot, Glen Brown, and I fan Kuo
}

\begin{abstract}
Background: Single-dose etomidate is used as an induction agent for rapid-sequence intubation and is associated with transient adrenal insufficiency. There is ongoing debate as to the clinical consequences of this transient adrenal insufficiency for critically ill patients.

Objective: To determine if the use of etomidate is associated with higher requirements for a vasopressor, relative to other induction agents, at a single time point ( $24 \mathrm{~h}$ after administration of the induction agent) in patients needing mechanical ventilation.

Methods: In this retrospective observational study utilizing electronic health records, a convenience sample of 50 patients who had undergone intubation in the emergency department with etomidate were matched (1:1) with patients who had received other induction agents. Matching was based on primary admitting diagnosis relating to the cause of shock, APACHE II (Acute Physiology and Chronic Health Evaluation II) score, age, and sex. All patients were subsequently admitted to critical care areas for management. As a surrogate marker of hemodynamic instability, the vasopressor dose was recorded $24 \mathrm{~h}$ after intubation. Vasopressor doses were converted to norepinephrine equivalents for comparison.
\end{abstract}

Results: The mean dose of vasopressors, in norepinephrine equivalents, was $4 \mu \mathrm{g} / \mathrm{min}^{-1}$ for patients receiving etomidate and $3 \mu \mathrm{g} / \mathrm{min}^{-1}$ for the control group (mean difference $0.7 \mu \mathrm{g} \mathrm{min}{ }^{-1}, 95 \%$ confidence interval [CI] -1.9 to $\left.3.2 \mu \mathrm{g} \mathrm{min} \operatorname{mos}^{-1}, p=0.61\right)$. Twelve of the patients in the etomidate group and 16 of those in the control group required the use of vasopressors at $24 \mathrm{~h}$ following intubation (odds ratio 2.3, 95\% CI 0.53 to $13.99, p=0.34$ ).

Conclusions: Single-dose etomidate does not adversely affect hemodynamic stability, as measured by the dose of vasopressors required at $24 \mathrm{~h}$ after administration.

Key words: etomidate, adrenal insufficiency, vasopressors, critical care, mechanical ventilation

Can J Hosp Pharm 2012;65(4):272-276

\section{RÉSUMÉ}

Contexte : Létomidate administré en dose unique est utilisé comme agent d'induction pour l'intubation en séquence rapide et est associé à une insuffisance surrénalienne transitoire. Il existe toujours une controverse quant aux conséquences cliniques de cette insuffisance surrénalienne transitoire chez les malades en phase critique.

Objectif : Déterminer si l'utilisation d'étomidate est associée à des besoins accrus en vasopresseurs, par rapport à d'autres agents d'induction, à un moment unique (24 heures après l'administration de l'agent d'induction) chez les patients ayant besoin de ventilation artificielle.

Méthodes : Dans le cadre de cette étude d'observation rétrospective réalisée à partir de dossiers médicaux électroniques, un échantillon de commodité de 50 patients ayant subi une intubation dans le service des urgences au moyen d'étomidate ont été appariés (1:1) avec des patients qui avaient reçu d'autres agents d'induction. L'appariement était fondé sur le diagnostic principal à l'admission relatif à la cause du choc, l'indice APACHE II (Acute Physiology and Chronic Health Evaluation II), l'âge et le sexe. Tous les patients ont été par la suite admis à des unités de soins intensifs pour être pris en charge. On a consigné la dose de vasopresseurs administrée 24 heures après l'intubation comme critère de substitution de l'instabilité hémodynamique. Les doses de vasopresseurs ont été converties en équivalents-norépinéphrine à des fins de comparaison.

Résultats : La dose moyenne de vasopresseurs, en équivalentsnorépinephrine, était de $4 \mu \mathrm{g} /$ minute chez les patients recevant de l'étomidate et de $3 \mu \mathrm{g} /$ minute chez les patients du groupe témoin (différence moyenne de $0,7 \mu \mathrm{g} /$ minute, intervalle de confiance [IC] à $95 \%$ : $-1,9$ à $3,2 \mu \mathrm{g} /$ minute, $p=0,61$ ). Douze des patients du groupe étomidate et 16 du groupe témoin ont eu besoin de vasopresseurs 24 heures après l'intubation (risque relatif approché de 2,3, IC à $95 \%: 0,53$ à 13,99, $p=0,34)$.

Conclusions : L'administration d'une dose unique d'étomidate n'affecte pas la stabilité hémodynamique, d'après les mesures des doses de vasopresseurs requises 24 heures après l'administration de l'étomidate.

Mots clés : étomidate, insuffisance surrénalienne, vasopresseurs, soins intensifs, ventilation artificielle

[Traduction par l'éditeur] 


\section{INTRODUCTION}

$\mathrm{E}$ tomidate is a sedative-hypnotic that has received much attention for its use in rapid-sequence intubation. Having demonstrated a desirable safety profile for patients with hemodynamic instability, as well as other complications, etomidate became a popular choice as a sedative for rapidsequence intubation. ${ }^{1}$ However, evidence has shown that it is associated with rapid-onset, transient adrenal insufficiency. ${ }^{2,3}$ As little as a single bolus dose of $0.2-0.4 \mathrm{mg} / \mathrm{kg}$ etomidate has been shown to cause an immediate effect on adrenal function. ${ }^{4}$ Etomidate produces adrenal insufficiency by blocking the function of the enzyme 11ß-hydroxylase, which is necessary for the production of physiologically active cortisol. ${ }^{5}$ Following clearance of etomidate from the body, production of active cortisol resumes, with normalization of adrenal function by $48 \mathrm{~h}$ after administration in most patients. ${ }^{6}$ Among patients in whom etomidate inhibits cortisol production sufficiently to have clinically relevant effects, such as the need for vasopressors to maintain systemic blood pressure, the effect begins within hours, peaks at about $24 \mathrm{~h}$, and resolves by $48 \mathrm{~h}$.

The clinical implications of transient adrenal insufficiency in critically ill patients have been debated. In particular, it is not clear that the adrenal insufficiency affects overall mortality. ${ }^{7-9}$ Despite this uncertainty about effect on mortality, many clinicians feel that the drug should be avoided because of its potential detrimental effects and ongoing controversy related to its use in critically ill patients. ${ }^{10-14}$

One measure of a potential detrimental effect of adrenal insufficiency is a requirement for pharmacologic support of perfusion and systemic blood pressure. Measurement of a surrogate marker, specifically the need for a vasopressor after etomidate, would further elucidate the relationship between etomidate and adrenal function impairment. Several studies have documented the need for a vasopressor in patients at some point following use of etomidate. ${ }^{15-17}$ In the study reported here, an attempt was made to quantify the need for pharmacologic support of the circulatory system, and the requirements for such support were compared between patients who received etomidate and similar patients who received alternative drugs for rapid-sequence intubation. Specifically, the objective was to determine if the use of etomidate was associated with higher requirements for a vasopressor, relative to other induction agents, at a single time point $(24 \mathrm{~h}$ after administration of the induction agent) among patients requiring mechanical ventilation. In this study, the need for a vasopressor was a surrogate marker for potential etomidate-induced adrenal insufficiency, since a deficiency of cortisol would produce hypotension.

\section{METHODS}

This retrospective observational study was based on a review of electronic health records for patients admitted to
St Paul's Hospital in Vancouver, British Columbia, with respiratory failure requiring endotracheal intubation using rapidsequence intubation, followed by admission to the intensive care unit (ICU) or the coronary care unit (CCU). Health Canada allows etomidate, which does not have approval for marketing in Canada, to be obtained through the Special Access Programme. A requirement of this program is that all patients receiving the drug be identified and recorded. Therefore, the study hospital maintains a specific database to record information for all patients receiving etomidate. This database was used to identify a convenience sample of 50 patients who had received etomidate in the emergency department between January 2006 and April 2010 and who were admitted to the ICU or CCU within $24 \mathrm{~h}$. The convenience sample was selected according to the availability of records for identifying patients who had received etomidate. Patients identified in the etomidate database as "unknown" were searched via medical records on the basis of sex (if available) and date of admission to the emergency department. The decision to use etomidate was made by the clinician at the time of intubation. The current investigators were not aware of any structured bias on the part of the clinicians in the use of etomidate versus other agents on the basis of hemodynamics. Rather, choice of drug was largely driven by the experience of the clinician doing the intubation.

The ICU maintains a database of patients who have been admitted to the ICU. This database was used to confirm whether the patients in the etomidate group had been admitted to the ICU within $24 \mathrm{~h}$ after intubation and to obtain the APACHE II (Acute Physiology and Chronic Health Evaluation II) score on admission, as well as the primary admitting diagnosis related to the cause of shock (septic, hypovolemic, or cardiogenic) or the cause of respiratory failure. In the case of patients admitted to the $\mathrm{CCU}$, electronic health records were consulted to confirm admission to the $\mathrm{CCU}$ and to determine the admitting diagnosis and/or cause of shock. For these patients, the APACHE II score was calculated manually; all data necessary for this manual calculation were available. Patients admitted to the CCU were included only if they had remained intubated for at least $24 \mathrm{~h}$, to ensure that they had actually experienced respiratory failure.

The ICU patient database for this period identified 518 patients eligible for use as controls, defined as patients who had undergone intubation in the emergency department and had been admitted to the ICU but who had not received etomidate. The control patients had received any single or combination of induction agents, including a single agent or combinations of opioids (such as morphine or fentanyl), benzodiazepines (such as midazolam), barbiturates (such as thiopental), propofol, or ketamine. 
Controls were matched 1:1 to the etomidate cases according to the following characteristics (listed in order of priority): primary admitting diagnosis related to cause of shock (septic, hypovolemic, or cardiogenic) or cause of respiratory failure, site of infection (for patients with septic shock), APACHE II score (on date of admission to ICU or CCU), age, and sex. Patients receiving etomidate who were admitted to the $\mathrm{CCU}$ were also matched to control patients from the ICU database according to the same criteria. If the admitting diagnosis for a patient in the etomidate group could not be matched to a control, the diagnosis deemed most similar in physiological effects was used for matching to a control patient.

The electronic health records for all selected patients (etomidate and control groups) were reviewed to determine patient characteristics, including inclusion and exclusion criteria, and treatment. Patients were excluded if they had used corticosteroids within 28 days before admission, including corticosteroids for any indication following rapid-sequence intubation up to the 24-h data collection time point. Patients were also excluded if death or transition to palliative treatment occurred within that same 24-h period. Other exclusion criteria were any previous or new diagnosis of adrenal insufficiency, administration of repeat doses of etomidate beyond 30 min after the initial dose, intubation by emergency health services personnel before presentation to the emergency department, and lack of data needed for evaluation of exclusion and inclusion criteria or determination of time of etomidate administration. For the included patients, the dose of vasopressor (norepinephrine, epinephrine, dopamine, vasopressin, and/or phenylephrine) given $24 \mathrm{~h}$ after intubation was recorded. If the time of intubation was not available from the health record, the ICU database time of intubation was used. The selection of the 24-h time point was based on findings of Vinclair and others, ${ }^{6}$ who suggested that the greatest increase in the cortisol precursor, a marker of etomidate-induced blockade of cortisol, occurred at $24 \mathrm{~h}$ (versus 12 or $48 \mathrm{~h}$ ).

All vasopressor dosages were converted to equivalent norepinephrine doses using the following conversion, previously adopted in the Vasopressin and Septic Shock Trial (VASST) ${ }^{18}$ : [norepinephrine $(\mu \mathrm{g} \mathrm{min}-1)]=\left[\right.$ dopamine $\left.\left(\mu \mathrm{g} \mathrm{kg} \mathrm{min}^{-1}\right) \div 2\right]$ $=\left[\right.$ epinephrine $\left.\left(\mu \mathrm{g} \mathrm{min}{ }^{-1}\right)\right]=\left[\right.$ phenylephrine $\left.\left(\mu \mathrm{g} \min ^{-1}\right) \div 10\right]$. From the VASST supplemental data for day 1 , it appears that 0.03 units $\mathrm{min}^{-1}$ decreased norepinephrine requirements by $11 \mu \mathrm{g} \mathrm{min}{ }^{-1} .{ }^{18}$ Therefore, we used the following conversion: vasopressin 0.03 units $\mathrm{min}^{-1}=$ norepinephrine $11 \mu \mathrm{g} \mathrm{min}$

Dobutamine administration was not included in the calculation, since it has a predominantly vasodilating action on the systemic circulation. It was anticipated that the detrimental effect of etomidate on the circulation would be vasodilation, and dobutamine would not have been used to counteract this effect. $^{19}$
A paired $t$ test was used to compare the mean difference in use of vasopressors between the 2 groups. The McNemar test was used to test whether the probability of vasopressor requirement was similar between the 2 groups. A $p$ value less than 0.05 was considered statistically significant.

\section{RESULTS}

Of the 50 patients in the etomidate group, 42 had been admitted to the ICU and 8 to the CCU. Patient characteristics were similar between the 2 groups in terms of age, sex, and APACHE II score (Table 1). In terms of the reason for intubation, the types of shock (septic, cardiogenic, or hypovolemic) were equally distributed between the 2 groups. The "other" category referred to reasons for intubation that did not fall into one of these 3 categories, such as seizures and intentional or unintentional poisonings. For 4 patients, the time of intubation was not available from the health record, and the ICU database time of intubation was used instead.

The use of etomidate was not associated with a higher requirement for a vasopressor, relative to other induction agents, $24 \mathrm{~h}$ after intubation. More specifically, the mean dose of vasopressor, in norepinephrine equivalents, was $4 \mu \mathrm{g} \mathrm{min}{ }^{-1}$ for the etomidate group and $3 \mu \mathrm{g} \mathrm{min}{ }^{-1}$ for the control group, with a mean difference between the 2 groups of $0.7 \mu \mathrm{g} \mathrm{min}^{-1}$ (95\% confidence interval $[\mathrm{CI}]-1.9$ to $3.2 \mu \mathrm{g} \mathrm{\textrm {min } ^ { - 1 }}, p=0.61$ ). There was also no difference in the proportion of patients who required treatment with a vasopressor $24 \mathrm{~h}$ after intubation: 12 patients in the etomidate group versus 16 patients in the control group (odds ratio $2.3,95 \%$ CI 0.53 to $13.99, p=0.34$ ).

\section{DISCUSSION}

In this study, there was no difference between etomidate and traditional sedatives in patients' requirement for a vasopressor $24 \mathrm{~h}$ after administration of the induction agent. This result suggests that the transient effect of etomidate on adrenal function does not cause any prolonged detrimental hemodynamic effect. It is also consistent with the findings of other recently published trials comparing etomidate with other induction agents in patients with sepsis, which found no difference in length of hospital stay or mortality ${ }^{20,21}$ but did not address the potential need for additional or increased therapies during the hospital stay. If etomidate caused clinically relevant hypotension, initiation or continuation of vasopressor therapies might be required, making care more complex, without any effect on length of stay or mortality. Because etomidate is used as an induction agent in a much broader population than patients with septic shock, the patient sample for this study was expanded beyond what has previously been studied to include all patients who received etomidate, regardless of the cause of shock and/or respiratory failure. However, no relevant incidents 
Table 1. Characteristics of Participants and Summary of Findings

\begin{tabular}{|c|c|c|}
\hline Characteristic & $\begin{array}{c}\text { Etomidate } \\
(n=50)\end{array}$ & $\begin{array}{l}\text { Control } \\
(n=50)\end{array}$ \\
\hline Age (years), mean* & 53 & 48 \\
\hline Sex, no. (\%) male & $36(72)$ & $31(62)$ \\
\hline Dose of etomidate $(\mathrm{mg})^{*}$ & 20 & NA \\
\hline \multicolumn{3}{|c|}{ Reason for mechanical ventilation, no. (\%) } \\
\hline Septic shock† & $16(32)$ & $16(32)$ \\
\hline Cardiogenic shock $\ddagger$ & $4(8)$ & $4(8)$ \\
\hline Hypovolemic shock§ & 3 (6) & $3(6)$ \\
\hline Other & $27(54)$ & $27(54)$ \\
\hline APACHE II score, mean* & 20 & 21 \\
\hline \multicolumn{3}{|c|}{ No. (\%) of patients receiving vasopressor } \\
\hline Any vasopressor & $12(24)$ & $16(32)$ \\
\hline Norepinephrine & $11(22)$ & $16(32)$ \\
\hline Dopamine & $1(2)$ & 0 \\
\hline Vasopressin & $4(8)$ & $6(12)$ \\
\hline $\begin{array}{l}\text { Mean dose of vasopressor across all } \\
\text { patients in group, norepinephrine } \\
\text { equivalents }\left(\mu \mathrm{g} \mathrm{min} \mathrm{min}^{-1}\right)\end{array}$ & 4 & 3 \\
\hline \multicolumn{3}{|c|}{$\begin{array}{l}\text { APACHE II = Acute Physiology and Chronic Health Evaluation II, NA = not applicable. } \\
\text { *Rounded to whole numbers. } \\
\text { †Septic shock: clinical scenario consistent with an infection, systemic inflammatory response } \\
\text { syndrome, and inadequate perfusion. } \\
\text { ‡Cardiogenic shock: objective evidence of inadequate tissue perfusion with no objective } \\
\text { measurements of hypovolemia and no evidence of infection or inflammation. } \\
\text { §Hypovolemic shock: objective evidence of inadequate tissue perfusion with no objective } \\
\text { evidence of cardiac dysfunction, infection, or other cause of perfusion abnormality. } \\
\text { ๆOther: patients presenting with a need for mechanical ventilation but not because of } \\
\text { inadequate tissue perfusion (e.g., seizure, drug toxicity). }\end{array}$} \\
\hline
\end{tabular}

of hypotension requiring ongoing vasopressor therapy were documented.

This study had certain limitations. Because it was a retrospective analysis, confounding by indication could have occurred during the patients' initial presentation, when the decision was made as to which induction agents should be used. Etomidate is better tolerated hemodynamically than other induction agents, and this characteristic may have played a role in which patients received it. However, anecdotal assessment of usage patterns throughout the study period indicated that etomidate was selected on the basis of physicians' familiarity with the drug and its options, rather than on the basis of patients' characteristics. However, this assessment may have been incorrect, and some undocumented selection criteria may in fact have been applied, resulting in bias in terms of who received the drug. There was also potential reporting bias, as information regarding the cause of shock and the severity of disease was gathered retrospectively, and documentation at the time of admission may not have been consistent. The sample size was chosen on the basis of convenience, and the study may therefore have been underpowered to find a difference in vasopressor dosages. However, given the lack of difference observed with the sample size used in the study, any difference in vasopressor requirements between the true patient populations would be small and potentially insignificant. Finally, we used $24 \mathrm{~h}$ after administration of etomidate as the time point for data collection on the basis of published data describing the time of maximum adrenal suppression by etomidate. ${ }^{6}$ Although there are no data definitively stating when the peak effect of adrenal insufficiency occurs, it is possible that the most potent effect of etomidate on adrenal function falls before or after this time point.

As the debate regarding the safety of etomidate for rapidsequence intubation continues, this study should offer some reassurance about the lack of a detrimental effect of this drug. These results, in conjunction with other published data, suggest that the transient effect of etomidate does not translate into hemodynamic instability. Pharmacists caring for patients during the hours following etomidate administration can be assured that the drug is not adversely affecting patients' requirements for vasopressors.

\section{References}

1. Bergen JM, Smith DC. A review of etomidate for rapid sequence intubation in the emergency department. J Emerg Med 1997;15(2):221-230.

2. Zed PJ, Mabasa VH, Slavik RS, Abu-Laban RB. Etomidate for rapid sequence intubation in the emergency department: is adrenal suppression a concern? CJEM 2006;8(5):347-350.

3. Mohammad Z, Afessa B, Finkielman JD. The incidence of relative adrenal insufficiency in patients with septic shock after the administration of etomidate. Crit Care 2006;10(4):R105.

4. Malerba G, Romano-Girard F, Cravoisy A, Dousset B, Nace L, Lévy B, et al. Risk factors of relative adrenocortical deficiency in intensive care patients needing mechanical ventilation. Intensive Care Med 2005;31(3): 388-392. 
5. Duthie DJ, Fraser R, Nimmo WS. Effect of induction of anaesthesia with etomidate on corticosteroid synthesis in man. Br J Anaesth 1985; 57(2):156-159.

6. Vinclair M, Broux C, Faure P, Brun J, Genty C, Jacquot C, et al. Duration of adrenal inhibition following a single dose of etomidate in critically ill patients. Intensive Care Med 2008;34(4):714-719.

7. Hohl CM, Kelly-Smith CH, Yeung TC, Sweet DD, Doyle-Waters MM, Schulzer M. The effect of a bolus dose of etomidate on cortisol levels, mortality, and health services utilization: a systematic review. Ann Emerg Med 2010;56(2):105-113.e5.

8. Cuthbertson BH, Sprung CL, Annane D, Chevret S, Garfield M, Goodman S, et al. The effects of etomidate on adrenal responsiveness and mortality in patients with septic shock. Intensive Care Med 2009; 35(11):1868-1876

9. Tekwani KL, Watts HF, Rzechula KH, Sweis RT, Kulstad EB. A prospective observational study of the effect of etomidate on septic patient mortality and length of stay. Acad Emerg Med 2009;16(1):11-14.

10. Jackson WL Jr. Should we use etomidate as an induction agent for endotracheal intubation in patients with septic shock? A critical appraisal. Chest 2005;127(3):1031-1038.

11. Walls RM, Murphy MF. Clinical controversies: etomidate as an induction agent for endotracheal intubation in patients with sepsis: continue to use etomidate for intubation of patients with septic shock. Ann Emerg Med 2008;52(1):13-14.

12. Sacchetti A. Etomidate: not worth the risk in septic patients. Ann Emerg Med 2008;52(1):14-16.

13. Kamp R, Kress JP. Etomidate, sepsis, and adrenal function: not as bad as we thought? Crit Care 2007;11(3):145.

14. Fengler BT. Should etomidate be used for rapid-sequence intubation induction in critically ill septic patients? Am J Emerg Med 2008; 26(2):229-232.

15. Hildreth AN, Mejia VA, Maxwell RA, Smith PW, Dart BW, Barker DE. Adrenal suppression following a single dose of etomidate for rapid sequence induction: a prospective randomized study. J Trauma 2008;65(3):573-579.

16. Baird CR, Hay AW, McKeown DW, Ray DC. Rapid sequence induction in the emergency department: induction drug and outcome of patients admitted to the intensive care unit. Emerg Med J 2009;26(8):576-579.
17. Ray DC, McKeown DW. Effect of induction agent on vasopressor and steroid use, and outcome in patients with septic shock. Crit Care 2007; 11(3):R56.

18. Russell JA, Walley KR, Singer J, Gordon AC, Hébert PC, Cooper DJ, et al.; VASST Investigators. Vasopressin versus norepinephrine infusion in patients with septic shock. $N$ Engl J Med 2008;358(9):877-887.

19. Majerus TC, Dasta JF, Bauman JL, Danziger LH, Ruffolo RR Jr. Dobutamine: ten years later. Pharmacotherapy 1989;9(4):245-259.

20. Tekwani KL, Watts HF, Sweis RT, Rzechula KH, Kulstad EB. A comparison of the effects of etomidate and midazolam on hospital length of stay in patients with suspected sepsis: a prospective, randomized study. Ann Emerg Med 2010;56(5):481-489.

21. Dmello D, Taylor S, O’Brien J, Matuschak GM. Outcomes of etomidate in severe sepsis and septic shock. Chest 2010;138(6):1327-1332.

Mary Elliot, BScPharm, ACPR, is a Clinical Pharmacist with Vancouver General Hospital, Vancouver, British Columbia.

Glen Brown, PharmD, FCSHP, BCPS(AQ), is a Clinical Pharmacy Specialist, Critical Care, with the Pharmacy Department, St Paul's Hospital, Vancouver, British Columbia. He is also an Associate Editor for the CJHP.

I fan Kuo, BSC(Pharm), ACPR, PharmD, is a Postdoctoral Research Fellow with the Faculty of Pharmaceutical Sciences, The University of British Columbia, Vancouver, British Columbia.

\section{Address correspondence to:}

Mary Elliot

Vancouver General Hospital

G-42 Ground 855 West 12th Avenue

Vancouver BC V5Z $1 \mathrm{M} 9$

e-mail: mary.elliot@vch.ca 